\title{
Arpada Tane Verimi ve Kalite Özellikleri Üzerine Genotip ve Çevrenin Etkileşimi
}

\author{
Ferhat KIZILGEÇI ${ }^{1}$ (D), Mehmet YILDIRIM ${ }^{2}$ (D) Cuma AKINCI ${ }^{3}$ (D), Önder ALBAYRAK $^{4}$ (D) \\ ${ }^{1}$ Mardin Artuklu Üniv. Kızıltepe Meslek Yüksek Okulu,Mardin 2,3,4Dicle Üniversitesi Ziraat Fakültesi Tarla Bitkileri Bölümü, Diyarbakır \\ 1https://orcid.org/0000-0002-7884-5463, ${ }^{2} \mathrm{https://orcid.org/0000-0002-6953-4479,}{ }^{3} \mathrm{https}: / / o r c i d . o r g / 0000-0002-3514-1052$, \\ ${ }^{4}$ https://orcid.org/0000-0003-2440-7748 \\ $\bowtie$ : ferhat_kizilgeci@hotmail.com
}

\section{ÖZET}

$\mathrm{Bu}$ çalışma, bazı arpa genotiplerinin tane verimi ve kalite özellikleri üzerine çeşit ve çevrenin etkilerini belirlemek amacıyla, 2011-2012 yılında Diyarbakır ve Mardin koşullarında yürütülmüştür. Araştırmada, 2 adet ticari çeşit ve 5 adet ileri hat kullanarak tane verimi, bin tane ağırlığı, hektolitre ağırlığı, protein içeriği, nişasta içeriği ve klorofil içeriği değerleri incelenmiştir. Elde edilen sonuçlara göre, genotip, çevre ve çeşit $\mathrm{x}$ çevre interaksiyonunun incelenen özellikler üzerine etkileri istatistikî olarak önemli bulunmuştur. Genotiplerin tane verimi 413.60-661.63 kg da-1 , bin tane ağırlı̆̆ $42.21^{-}$ $45.02 \mathrm{~g}$, hektolitre ağırlığ $158.92-66.39 \mathrm{~kg} / \mathrm{hl}$, tanede protein içeriği \%11.70-14.24, tanede nişasta içeriği \%59.8-61.2 ve klorofil içeriği 44.448.6 değerleri arasında değişmiştir. Her iki lokasyonda da Altıkat çeşidi en yüksek tane verimi değerine sahip olmuştur. DZA-7, DZA-8 ve Dicle 1 hatları protein içeriği, hektolitre ağırlığı ve nişasta içeriği özellikleri yönünden ön plana çıkmışlardır. Biplot analizi ile tüm özellikler incelendiğinde tane verimi, bin tane ağırlığı ve SPAD değeri aynı grupta yer alırken protein içeriği, nişasta içeriği ve hektolitre ağırlığı özellikleri aynı grupta yer almıştır.

Araştırma Makalesi
Makale Tarihçesi
Geliş Tarihi : 18.01 .2019
Kabul Tarihi $\quad: 04.03 .2019$

Anahtar Kelimeler
Arpa
Biplot
Protein içeriği
SPAD
Tane verimi

\section{Genotype and Environment Effects on the Grain Yield and Quality Traits of Some in Barley Genotypes}

\begin{abstract}
The purpose of this study was to determine genotype and environment effects on the grain yield and its component of some barley genotypes in Diyarbakır and Mardin conditions in 2011-2012. In the study, 2 commercial varieties and 5 advanced lines were used as a material. Grain yield, thousand grain weight, test weight, protein content, starch content and SPAD value were measured. Results varied between 413.60-661.63 kg da-1 for grain yield, 42.21-45.02 $\mathrm{g}$ for thousand grain weight, $58.92-66.39 \mathrm{~kg} \mathrm{hl}^{-1}$ for test weight, $11.70-14.24$ $\%$ for grain protein content, 59.8-61.2 \% for grain starch content and 44.4-48.6 unit for SPAD value. Altikat sustained the highest grain yield in both locations. DZA-7, DZA-8 and Dicle 1 advanced lines showed high performance in terms of protein contents, starch content and test weight. When all traits were evaluated using the Biplot analysis, grain yield, thousand grain weight and SPAD were involved in the same group, while protein content, starch content, test weight were grouped in the other group.
\end{abstract}

\section{Research Article}

$\begin{array}{ll}\text { Article History } & \\ \text { Received } & : 18.01 .2019 \\ \text { Accepted } & : 04.03 .2019\end{array}$

Keywords

Barley

Biplot

Protein content

SPAD

Grain yield

To Cite : Kızılgeçi F, Yıldırım M, Akıncı C, Albayrak Ö 2019. Arpada Tane Verimi ve Kalite Özellikleri Üzerine Genotip ve Çevrenin Etkileşimi. KSÜ Tarım ve Doğa Derg 22(3): 346-353. DOIः 10.18016/ksutarimdoga.vi.499013.

\section{GİİŞ}

Arpa (Hordeum vulgare L.) Dünyada üretim miktarı ve yetiştirme alanı bakımından mısır, çeltik ve buğdaydan sonra en önemli 4. tahıl bitkisidir (Kizilgeci ve ark., 2018). Türkiye arpa yetiştiriciliği için uygun çevre koşullarına sahip olmasından dolayı buğdaydan sonra ikinci sırada yer almaktadır. Türkiye'de, 2.7 milyon hektar alanda yıllık 6.7 milyon ton üretim ve ortalama $248.1 \mathrm{~kg} \mathrm{da}^{-1}$ verime sahiptir (TUIK, 2018). Geçmişte insan beslenmesinde kullanılan arpa günümüzde büyük ölçüde hayvan yemi ve malt sanayinde kullanılmaktadır. İnsan nüfusunun artması beraberinde hayvansal besinlere olan ihtiyacı da arttırmaktadır. Geçit (1982) hayvan yetiştiriciliğinde yoğun olarak arpanın kullanılması nedeniyle arpa üretiminde birim alandan elde edilen 
ürünün miktarının arttırması gerektiğini bildirmiştir. Ancak günümüzde ekim alanlarının son sınırına ulaşmış olması nedeniyle birim alandan en yüksek verimin alınabileceği çeşitlerin geliştirilmesi büyük önem taşımaktadır. $\mathrm{Bu}$ nedenle birçok ıslah programının asıl ve en önemli amacı birim alandan elde edilecek ürün miktarının ve kalitesinin artırılmasına yönündedir. Arpa tane bileşimi ve kalitesi sıcaklık, gün uzunluğu, su miktarı, topraktaki besin elementinin durumu gibi çevresel faktörlerden etkilenmektedir (Jadhav ve ark., 1998). Vaize ve ark. (2015) genotip $\times$ çevre etkileşim etkilerinin değerlendirilmesi ve farklı çevre koşullarında kararlı ve yüksek performanslı çeşitlerin tanımlanmasının bitki ıslahında çok önemli olduğunu bildirmiştir. Birçok çalışmada, çeşitlerin verim, tarımsal özellikler ve kalite özelliklerinin çeşit ve çevreye göre değiştiği belirtilmiştir (Iranavi ve ark., 2008; Fotokian ve ark., 2014; Ahmadi ve ark., 2016). Genotip çevre verilerinin analizi için temel istatistiksel metotlardan biri olarak, GGE biplot analizi Yan ve ark. (2000), Yan ve Kang (2002) ve Yan ve Tinker (2006) tarafindan geliştirilmiştir. $\mathrm{Bu}$ yöntem, son zamanlarda farklı genotipler ile farklı çevrelerde veya yıllarda yürütülen çalışmalarda birçok özelliği aynı anda görsel açıdan değerlendirme firsatı sağlaması ve seleksiyonda başarıyı etkilediği için bitki ıslahında uygulanan yenilikçi bir yöntem olarak kabul edilmiştir (Yau, 1995; Yan ve ark., 2007). Bu çalışma, bazı arpa genotiplerinin verim ve kalite özelliklerini farklı lokasyonlarda incelemek ve biplot analizi yöntemiyle değerlendirmek amaciyla yürütülmüştür.

\section{MATERYAL ve METOT}

Araştırma, 2011-2012 yetiştirme sezonunda Dicle Üniversitesi Ziraat Fakültesi araştırma ve uygulama alanı ile Mardin ili Kızıltepe ilçesinde yürütülmüştür. Materyal olarak 2 adet ticari çeşit (Altıkat ve Samyeli) ve 5 adet ileri arpa hattı kullanılmıştır (Çizelge 1).

Diyarbakır ve Mardin deneme alanlarının toprak yapısı sırasıyla, killi-tınlı ve killi bünyeli olup, her iki lokasyon için $\mathrm{pH}$ değerleri 7.3-7.7 arasında hafif alkali, organik madde içeriği düşük ve fosfor bakımından fakir, potasyum kapsamı çok yüksek ve tuzluluk sorunu olmayan alanlardır. Her iki lokasyona ait iklim verileri Çizelge 2'de verilmiştir. Toplam yağış miktarı yönünden Diyarbakır lokasyonu Mardin lokasyonuna göre daha fazla yağış almıştır. Mardin lokasyonunda bitki gelişimi için önemli olan Nisan ve Mayıs ayında (sırasıyla, $13 \mathrm{~mm}$ ve $5.6 \mathrm{~mm}$ ) yağışın, kritik seviye yetersiz olması nedeniyle sulama yapılmıştır.

Çizelge 1. Araştırmada kullanılan arpa genotiplerine ait başak tipi özellikleri

\begin{tabular}{|c|c|}
\hline Genotip & Başak Tipi \\
\hline Altıkat & 6 sıralı \\
\hline Samyeli & 2 sıralı \\
\hline Dicle 1 & 2 siralı \\
\hline DZA-07 & 2 siralı \\
\hline DZA-08 & 2 siralı \\
\hline DZA-13 & 2 siralı \\
\hline DZA-6-1 & 6 siralı \\
\hline
\end{tabular}

Denemeler, her iki lokasyonda Kasım ayı içerisinde tesadüf blokları deneme desenine göre dört tekrarlamalı olarak kurulmuştur. Ekim, metrekareye 450 tohum gelecek şekilde $4.8 \mathrm{~m}^{2}(1.2 \mathrm{~m} \mathrm{x} 4 \mathrm{~m})$ parsellere 6 sıralı parsel ekim mibzeri ile yapılmıştır. Çalışmada, $6 \mathrm{~kg} \mathrm{da}^{-1}$ saf fosfor $\left(\mathrm{P}_{2} \mathrm{O}_{5}\right)$ ve $6 \mathrm{~kg} \mathrm{da}^{-1} \mathrm{saf}$ azot $(\mathrm{N})$ hesabına göre ekimle beraber kompoze gübre (20:20:0) uygulanmıştır. Bitkiler kardeşlenme döneminde iken üst gübre olarak dekara $6 \mathrm{~kg}$ saf N hesabına göre üre (\%46) uygulanmıştır. Bitkilerin gelişim dönemi boyunca görülen hastalık ve zararlılar yönünden gözlemlenmiş, gerekli görülen durumlarda kimyasal mücadele yapılmıştır.

Deneme parselleri Haziran ayının son haftası elle hasat edilmiştir. Araştırmada; klorofil içeriği, tane verimi, bin tane ağırlığ 1 , tanede protein içeriği, tanede nişasta içeriği ve hektolitre ağırlığ incelenmiştir.

Klorofil içeriği, bitkiler başaklanma döneminde iken her parselden rastgele seçilen 10 bitkinin bayrak yaprağına zarar vermeden klorofil miktarını dolaylı olarak ölçen SPAD-502 (Minolta, Japonya) ile havanın bulutsuz ve açık olduğu 11-12 saatleri arasında ölçülmüştür.

Çizelge 2. Diyarbakır ve Mardin illerine ait 2011-2012 yılı meteorolojik verileri

\begin{tabular}{|c|c|c|c|c|c|c|}
\hline \multirow{2}{*}{ Aylar } & \multicolumn{3}{|c|}{ Diyarbakır } & \multicolumn{3}{|c|}{ Mardin } \\
\hline & Sicaklık $\left({ }^{\circ} \mathrm{C}\right)$ & Yağış $(\mathrm{mm})$ & Nisbi Nem(\%) & Sicaklık $\left({ }^{\circ} \mathrm{C}\right)$ & Yağış $(\mathrm{mm})$ & Nisbi Nem(\%) \\
\hline Kasım & 6.1 & 73.0 & 58.5 & 6.7 & 45.2 & 51.3 \\
\hline Aralık & 2.3 & 40.2 & 73.9 & 5.9 & 41.2 & 48.1 \\
\hline Ocak & 2.4 & 78.3 & 84.5 & 3.1 & 74.8 & 77.6 \\
\hline Şubat & 2.0 & 74.4 & 68.2 & 2.9 & 107.4 & 59.3 \\
\hline Mart & 5.2 & 44.0 & 58.6 & 5.0 & 44.4 & 53.2 \\
\hline Nisan & 15.2 & 26.2 & 58.4 & 16.4 & 13.0 & 41.3 \\
\hline Mayıs & 19.6 & 41.0 & 58.2 & 20.3 & 5.6 & 39.2 \\
\hline Haziran & 27.5 & 7.0 & 28.0 & 27.6 & 5.2 & 21.3 \\
\hline Toplam/ortalama & 10.0 & 384.1 & 61.0 & 11.0 & 336.8 & 48.9 \\
\hline
\end{tabular}


Tanede protein içeriği (\%), tanede nişasta içeriği (\%) ve hektolitre ağırlığ $\left(\mathrm{kg} \mathrm{hl}^{-1}\right)$ taneler öğütülmeden NIT1246 grain analyzer (Foss) cihazıyla ölçülmüştür. Tane verimi, parsellerin hasat harman işlemlerinden sonra tanelerin tartılmasıyla belirlenen parsel veriminin dekara çevrilmesiyle hesaplanmıştır.

Elde edilen verilerin varyans analizleri JMP 10 paket programı kullanılarak yapılmıştır. Önemli bulunan özelliklerin gruplandırmaları LSD testi ile yapılmıştır. Genotip/çevre arasındaki ilişki Biplot analiz yöntemi ile gösterilmiştir (Yan, 2001).

\section{BULGULAR VE TARTIŞMA}

\section{Klorofil İçeriği (SPAD)}

Çizelge 3’te birleştirilmiş varyans analizi sonucuna göre verilen lokasyon, genotip ve genotip $\mathrm{x}$ çevre interaksiyonu istatistiksel olarak önemli (\%1) bulunmuştur. Klorofil içeriğinin her iki çevreden etkilendiği görülmektedir. Diyarbakır ve Mardin lokasyonlarında elde edilen klorofil içeriği değerleri sırasıyla $45.4-51.4$ ve $37.3-51.4$ arasında değişim göstermiştir. Genotiplerin lokasyon ortalamalarına göre en yüksek SPAD değeri 51.4 ile Altıkat çeşidinde elde edilirken en düşük SPAD değer ise 43.6 ile DZA6-1 hattında elde edilmiştir. Diyarbakır lokasyonunun (48.6) ortalama klorofil içeriği değeri Mardin lokasyonuna (44.4) göre daha yüksek bulunmuştur. Klorofil içeriğinin ölçüldüğü başaklanma döneminde Mardin lokasyonunda sıcaklığın yüksek ve yağışın düşük olması arpa bitkisinin bayrak yaprağındaki klorofil içeriği üzerine olumsuz etkiye neden olduğu düşünülmektedir. Allakhverdiev ve ark., (2008) abiyotik stres faktörlerinin bitkide fotosentez sürecini ciddi şekilde olumsuz etkilediğini ve Mishra ve ark. (2014) kuraklık ve sıcaklık stresinin klorofil içeriği, photosystem II (PSII) etkinliği, stoma iletkenliği, net asimilasyon oranı gibi fizyolojik parametrelerini büyük ölçüde azalttığını bildirmişlerdir. Kızılgeçi ve ark. (2016a), Mardin ve Diyarbakır lokasyonlarında yaptıkları çalışmalarında arpada klorofil içeriği değerinin sirasıyla, $45.33-52.13$ ve $41.15-48.88$ değerleri arasında değişim gösterdiğini bildirmişlerdir.

Çizelge 3. 2011-2012 üretim sezonunda iki çevrede denenen 7 arpa genotipinin tane verimi ve bazı kalite özelliklerine ilişkin birleştirilmiş varyans analizi sonuçları

\begin{tabular}{|l|c|c|c|c|c|c|c|}
\hline Kaynak & SD & SPAD & Tane Verimi & Bin Tane Ağırlığı & $\begin{array}{l}\text { Hektolitre } \\
\text { Ăğırlığ1 }\end{array}$ & $\begin{array}{l}\text { Protein } \\
\text { İceriği }\end{array}$ & $\begin{array}{l}\text { Nişasta } \\
\text { İçeriği }\end{array}$ \\
\hline Lokasyon & 1 & $249.06^{* *}$ & $151967.6^{* *}$ & $89^{* *}$ & $34.13^{* *}$ & $11.07^{* * *}$ & $9.19^{* *}$ \\
\hline Hata1 & 6 & 8.86 & 34927.99 & 8.49 & 5.36 & 1.67 & 0.54 \\
\hline Genotip & 6 & $49.86^{* *}$ & $33532.81^{* *}$ & 12.29 & $81.77^{* *}$ & $7.78^{* *}$ & $2.41^{* *}$ \\
\hline GenotipxLokasyon & 6 & $46.59^{* *}$ & 11440.72 & $16.95^{*}$ & $11.9^{* *}$ & $2.46^{* *}$ & 0.86 \\
\hline Hata 2 & 36 & 11.93 & 7197.11 & 6.27 & 2.54 & 0.55 & 0.4 \\
\hline V.K. \% & & 7.41 & 16.7 & 1.05 & 2.5 & 5.91 & 1.05 \\
\hline
\end{tabular}

*,** \%5, \%1 düzeyinde önemli

\section{Bin Tane Ağırlığı (g)}

Arpada önemli bir kalite kriteri olan bin tane ağırlığı; tanenin dolgunluğu, iriliği ve nişasta içeriğini hakkında bilgi vermektedir. Birleşik varyans analizine göre lokasyon ve genotip x lokasyon interaksiyonu istatistiki yönden yüksek düzeyde önemli (\%1) bulunmuştur. Genotipler arası farklılıklar ise önemli bulunmamıştır (Çizelge 3). Diyarbakır ve Mardin lokasyonlarında arpa genotplerinden elde edilen ortalama bin tane ağırlığı değerleri sirasiyla, $40.54 \mathrm{~g}$ $45.16 \mathrm{~g}$ ve $42.35 \mathrm{~g}-48.49 \mathrm{~g}$ arasında değişim göstermiştir. Lokasyon ortalamalarına göre en düşük bin tane ağırlığı değeri DZA-13 (42.21g) hattında elde edilirken en yüksek değer Samyeli (45.02 g) çeşidinde elde edilmiştir. Bin tane ağırlığında görülen farklılık daha çok çeşitlerin genetik yapısından kaynaklanmaktadır (Öztürk ve ark., 2007). Bin tane ağırlığı yönünden lokasyon ortalamaları Diyarbakır lokasyonu $42.10 \mathrm{~g}$ ve Mardin lokasyonunda $44.62 \mathrm{~g}$ olduğu belirlenmiştir. Mardin lokasyonunda arpanın tane dolum döneminde düşen yağış miktarı Diyarbakır lokasyonunun çok altında gerçekleşmiştir. $\mathrm{Bu}$ dönemde Mardin lokasyonunda yapılan sulamanın etkisiyle bin tane ağırlığı yüksek bulunmuştur. Çiçeklenme ve başaklanma döneminde yapılacak olan sulamanın, tane iriliği ve yeknesaklığı ile yakından ilgili olup bin tane ağırlığ (Doorenbos ve Kassam, 1979).

\section{Hektolitre Ağırlığı (kg hl-1)}

Hektolitre ağırlığı tane dolgunluğunu belirleme yönünden önemli kalite unsurdur. Birleştirilmiş varyans analiz tablosu incelendiğinde (Çizelge 2), genotip, lokasyon ve genotip x lokasyon interaksiyonu istatistiki olarak \%1 düzeyinde önemli olduğu görülmektedir. Diyarbakır lokasyonunda hektolitre ağırlığ $68.07-58.44 \mathrm{~kg} \mathrm{hl}^{-1}$ ve Mardin lokasyonunda 65.40-59.21 kg hl-1 değerleri aralığında değişim gösterdiği görülmüştür. Genotiplerin lokasyon ortalamalarına göre en düşük hektolitre ağırlığı 58.92 $\mathrm{kg} \mathrm{hl}^{-1}$ ile DZA-6-1 hattında elde edilirken, en yüksek hektolitre ağırlığı $66.39 \mathrm{~kg} \mathrm{hl}^{-1}$ ile Dicle 1 hattında 
belirlenmiştir. Lokasyon ortalamaları incelendiğinde, Diyarbakır lokasyonunda $\left(63.58 \mathrm{~kg} \mathrm{hl}^{-1}\right)$ elde edilen hektolitre ağırlığı değeri Mardin lokasyonundan (62.02 $\left.\mathrm{kg} \mathrm{hl}{ }^{-1}\right)$ yüksek bulunmuştur. Çalışmada genotip ve çevre koşullarının hektolitre ağırlığı özelliği üzerine etkide bulunduğu görülmüştür. Kizilgeci ve ark. (2018) hektolitre ağırlığı tanenin biçimine, yoğunluğuna ve tane ebadına göre farklılıklar gösterdiğini bildirmişlerdir. Arpada hektolitre ağırlığının 64-66 kg arasında olması düşük, 66-68 kg arasında olması orta ve $68 \mathrm{~kg}$ ve üzeri ise yüksek olarak değerlendirilmektedir (Geçit, 2016). Bu araştırmada yalnızca Dicle 1 hattı Diyarbakır lokasyonunda yüksek hektolitre ağırlığı grubunda yer almıştır. Araştırmada kullanılan altı sıralı arpa genotipleri (Altikat ve DZA-1-6) beklenildiği gibi

düşük hektolitre ağırlığı değerine sahip olmuşlardır.

\section{Tane Verimi (kg da-1)}

Arpa genotiplerinin birleşik varyans analiz sonucuna göre, lokasyon ve genotipler arası farklılıklar istatistiksel anlamda çok önemli görülürken, genotip x lokasyon interaksiyonu önemsiz bulunmuştur (Çizelge 3). Tane verimi Diyarbakır lokasyonunda 590.97$327.33 \mathrm{~kg} \mathrm{da}^{-1}$ ve Mardin lokasyonlarında 661.63$479.62 \mathrm{~kg} \mathrm{da}^{-1}$ arasında değişim gösterdiği belirlenmiştir. Genotiplerin lokasyon ortalamalarına göre en yüksek tane verimi Altıkat $\left(661.63 \mathrm{~kg} \mathrm{da}^{-1}\right)$ çeşidinde belirlenirken en düşük tane verimi DZA-13 (413.60 kg da-1) hattında olduğu görülmüştür (Çizelge 4).

Çizelge 4. Diyarbakır ve Mardin lokasyonlarında kullanılan arpa genotiplerinin tane verimi ve kalite özelliklerine ait ortalama değerleri ve ortalamaların farklılık gruplandırmaları

\begin{tabular}{|c|c|c|c|c|c|c|c|c|c|}
\hline Özellikler & Lokasyon & Altıkat & Samyeli & Dicle1 & DZA-07 & DZA-08 & DZA-13 & DZA-6-1 & Ortalama \\
\hline \multirow{3}{*}{ SPAD } & Diyarbakır & $51.4 \mathrm{a}$ & $50.3 \mathrm{a}$ & $48.1 \mathrm{c}$ & $45.4 \mathrm{~d}$ & $48.4 \mathrm{bc}$ & $47.0 \mathrm{~cd}$ & $49.9 \mathrm{ab}$ & $48.6 \mathrm{a}$ \\
\hline & Mardin & $51.4 \mathrm{a}$ & $43.2 \mathrm{bc}$ & $45.1 \mathrm{ab}$ & $47.5 \mathrm{ab}$ & $44.8 \mathrm{ab}$ & $41.6 \mathrm{bc}$ & $37.3 \mathrm{c}$ & $44.4 \mathrm{~b}$ \\
\hline & Ortalama & $51.4 \mathrm{a}$ & $46.8 \mathrm{~b}$ & $46.6 \mathrm{~b}$ & $46.4 \mathrm{~b}$ & $46.6 \mathrm{~b}$ & $44.3 \mathrm{~b}$ & $43.6 \mathrm{~b}$ & 46.53 \\
\hline \multirow{3}{*}{$\begin{array}{l}\text { Tane } \\
\text { Verimi } \\
\left(\mathrm{kg} \mathrm{da}^{-1)}\right.\end{array}$} & Diyarbakır & $590.97 \mathrm{a}$ & $473.3 \mathrm{~b}$ & $433.75 b c$ & $470.94 \mathrm{~b}$ & $499.34 \mathrm{~b}$ & $327.33 \mathrm{~d}$ & $380.69 \mathrm{~cd}$ & $453.76 \mathrm{~b}$ \\
\hline & Mardin & 661.63 & 591.58 & 521.58 & 555.45 & 479.62 & 499.88 & 595.87 & $557.95 \mathrm{a}$ \\
\hline & Ortalama & $626.30 \mathrm{a}$ & $532.44 \mathrm{ab}$ & $477.67 \mathrm{bc}$ & $513.19 b$ & $489.48 \mathrm{bc}$ & $413.60 \mathrm{c}$ & $477.67 \mathrm{bc}$ & 505.85 \\
\hline \multirow{3}{*}{$\begin{array}{l}\text { Bin Tane } \\
\text { A } \breve{g ̆}_{1} \log _{1}(\mathrm{~g})\end{array}$} & Diyarbakır & 42.10 & 41.56 & 42.24 & 40.54 & 45.16 & 40.92 & 42.18 & $42.10 \mathrm{~b}$ \\
\hline & Mardin & 47.04 & 48.49 & $42.35 \mathrm{~b}$ & 44.09 & $43.60 \mathrm{~b}$ & 43.51 & 43.27 & $44.62 \mathrm{a}$ \\
\hline & Ortalama & 44.57 & 45.02 & 43.30 & 42.31 & 44.38 & 42.21 & 42.72 & 43.36 \\
\hline \multirow{3}{*}{$\begin{array}{l}\text { Hektolitre } \\
\text { ağırlığ } \\
\left(\mathrm{kg} \mathrm{ha}^{-1}\right)\end{array}$} & Diyarbakır & $59.64 \mathrm{c}$ & $65.42 \mathrm{~b}$ & $68.07 \mathrm{a}$ & $66.7 \mathrm{ab}$ & $67.15 \mathrm{ab}$ & $59.64 \mathrm{c}$ & $58.44 \mathrm{c}$ & $63.58 \mathrm{a}$ \\
\hline & Mardin & $60.37 \mathrm{~cd}$ & $65.40 \mathrm{a}$ & $64.70 \mathrm{a}$ & $62.98 \mathrm{ab}$ & $62.07 \mathrm{bc}$ & $59.21 \mathrm{~d}$ & $59.40 \mathrm{~d}$ & $62.02 \mathrm{~b}$ \\
\hline & Ortalama & $60.00 \mathrm{c}$ & 65.41ab & $66.39 a$ & $64.84 \mathrm{ab}$ & $64.61 \mathrm{~b}$ & $59.43 c$ & $58.92 \mathrm{c}$ & 62.80 \\
\hline \multirow{3}{*}{$\begin{array}{l}\text { Tanede } \\
\text { Protein } \\
\text { İçeriği (\%) }\end{array}$} & Diyarbakır & $10.5 \mathrm{~d}$ & $12.6 \mathrm{c}$ & $14.2 \mathrm{a}$ & $13.7 \mathrm{ab}$ & $13.9 \mathrm{a}$ & $12.6 \mathrm{c}$ & $12.6 \mathrm{c}$ & $12.85 \mathrm{~b}$ \\
\hline & Mardin & $12.9 \mathrm{c}$ & $15.0 \mathrm{a}$ & $14.3 \mathrm{a}$ & $14.7 \mathrm{a}$ & $14.0 \mathrm{ab}$ & $12.4 \mathrm{c}$ & $12.9 \mathrm{c}$ & $13.74 \mathrm{a}$ \\
\hline & Ortalama & $11.70 \mathrm{c}$ & $13.77 \mathrm{a}$ & $14.24 \mathrm{a}$ & $14.18 \mathrm{a}$ & $13.96 \mathrm{a}$ & $12.49 \mathrm{bc}$ & $12.73 \mathrm{~b}$ & 13.3 \\
\hline \multirow{3}{*}{$\begin{array}{l}\text { Tanede } \\
\text { Nişasta } \\
\text { İçeriği (\%) }\end{array}$} & Diyarbakır & $60.7 \mathrm{bc}$ & $61.4 \mathrm{ab}$ & $61.0 \mathrm{~b}$ & $61.5 \mathrm{ab}$ & $62.2 \mathrm{a}$ & $60.0 \mathrm{c}$ & $59.9 \mathrm{c}$ & $60.94 a$ \\
\hline & Mardin & 60.1 & 60.0 & 60.7 & 60.4 & 60.3 & 59.8 & 59.7 & $60.13 \mathrm{~b}$ \\
\hline & Ortalama & $60.4 \mathrm{bc}$ & $60.7 \mathrm{ab}$ & $60.9 \mathrm{ab}$ & $61.0 \mathrm{ab}$ & $61.2 \mathrm{a}$ & $59.9 \mathrm{c}$ & $59.8 \mathrm{c}$ & 60.54 \\
\hline
\end{tabular}

Aynı harf ile gösterilen ortalamalar arasındaki fark yoktur.

Altıkat çeşidi her iki lokasyonda en yüksek tane verimine sahip olmuştur. Kendal ve ark. (2014) 20112012 üretim döneminde Diyarbakır koşullarında yürüttükleri çalışmalarında en yüksek tane verimi değerini Altıkat çeşidinde elde ettiklerini bildirmişlerdir. Mardin lokasyonunda arpa genotipleri arasında tane verimi yönünden istatistiki anlamda farklılıklar ortaya çıkmamasına rağmen altı sıralı arpa genotipleri iki sıralı arpalara göre daha yüksek verime sahip olmuştur. Ekolojik farklılıklar tane verimi üzerine olumlu veya olumsuz yönde etkiye sahip olduğundan genotiplerin farklı çevrelerde farklı performans göstermesi beklenilen bir sonuçtur. Her bitkinin isteği olan uygun çevre koşulları her yerde mümkün olmamaktadır. Birçok araştırmacının yaptıkları çalışmalarında arpanın tane verimi üzerine çeşitlerin, çevre faktörlerinin ve kültürel işlemlerin etki ettiğini bildirmişlerdir (Çölkesen ve ark., 1994; Akıncı ve ark., 1999; Akıncı ve Yıldırım, 2009; Akıncı ve ark., 2001; Kaydan ve Yağmur, 2007; Kılıç ve ark., 2010; Aydoğan ve ark., 2011; Kızılgeçi ve ark., 2016a; Kızılgeçi ve ark., 2016b).

\section{Tanede Protein İçeriği (\%)}

Arpa tanesinin protein içeriği değeri onun son ürün olarak kullanım amacını belirlemede önemli bir kriterdir. Özellikle malt sanayi için tane protein içeriği değerinin düşük olması istenilirken yem sanayinde ise bu değerin yüksek olması arzu edilmektedir. Yapılan varyans analizine göre genotip, lokasyon ve genotip $\mathrm{x}$ lokasyon interaksiyonu istatistiki olarak önemli $(\mathrm{P}<0.01)$ bulunmuştur (Çizelge 3$)$. Bu bulgulara göre tanede protein içeriğinin genotip ve çevreden etkilendiğini göstermektedir. Diyarbakır 
lokasyonunda protein içeriği değeri \%12.6-14.2 arasında değişim gösterirken Mardin lokasyonunda ise \%12.4-15.0 değerleri arasında değiştiği görülmüştür. Lokasyon ortalamalarına göre en yüksek protein içeriği \%14.24 ile Dicle 1 hattında, en düşük protein içeriği değeri ise \%11.70 ile Altıkat çeşidinde belirlenmiştir. Tanede protein içeriği, Mardin lokasyonu ortalaması \%13.74 iken Diyarbakır lokasyonu ortalaması \%12.85 olduğu görülmektedir. Tanenin protein içeriği değerinin yüksek olması özellikle yemlik olarak kullanılması için daha uygundur. Bu çalışmada söz konusu özellik yönünden Dicle 1, DZA-7 ve DZA-8 hatları ön plana çıkmıştır. Araştırmanın yürütüldüğü Mardin lokasyonunda protein oluşumu döneminde yağış miktarının düşük ve sıcaklığın yüksek olmasından dolayı protein içeriği Diyarbakır lokasyonuna göre yüksek bulunmuştur. Tekdal ve ark. (2013) yağışın fazla olduğu veya sulu koşullarda yetiştirilen tahılların protein içeriğinin düşük olduğunu rapor etmektedir. Elgün ve ark. (2001), tahıllarda protein miktarının çeşit, çevre ve toprak faktörlerine göre değiştiğini ve topraktaki alınabilir azot oranı arttıkça tanedeki protein miktarının da yükseldiğini bildirmişlerdir.

\section{Tanede Nişasta İçeriği (\%)}

Tanenin en önemli bileşenlerinden biri olan nişasta, tanenin kuru ağırlığının yaklaşık olarak \%70'ini oluşturmaktadır. Ele alınan özelliğe ait varyans analizi tablosu incelendiğinde (Çizelge 3), genotip ve lokasyonlar arası farklılıklar istatistiki olarak çok önemli $(\mathrm{P} \leq 0.01)$ bulunurken, genotip $\mathrm{x}$ lokasyon interaksiyonu ise önemsiz bulunmuştur. Diyarbakır lokasyonunda tanede nişasta içeriği değerleri \%59.962.2 ve Mardin lokasyonunda \%59.7-60.7 değerleri aralığında değişim gösterdiği görülmüştür. Genotipler arasında tanede nişasta içeriği yönünden farklılıklar sadece Diyarbakır lokasyonunda görülmüştür. Mardin lokasyonunda ise benzer bulunmuştur. Arpa genotiplerinin lokasyon ortalamalarına göre en düşük tanede nişasta içeriği \%59.8 ile DZA-6-1 hattında görülürken, en yüksek değer ise \%61.2 ile DZA-08 hattında belirlenmiştir. Bu çalışmaya benzer olarak Kızılgeçi ve ark. (2016a) Diyarbakır ve Mardin koşullarında yürüttükleri çalışmalarında, Diyarbakır koşullarında en yüksek tanede nişasta içeriği değerlerini elde ettiklerini bildirmişlerdir. Tanede nişasta içeriğinin Diyarbakır'da yüksek bulunmasının nedeni başaklanma döneminde havanın nisbi neminin Mardin lokasyonuna göre daha yüksek olmasından dolayı olduğu düşünülmektedir.

\section{İncelenen Özelliklerin Korelasyon Katsayısı Analizi}

Tane verimini artırma için verim ve verim unsurları arasındaki ilişkiyi bilmek önemlidir. Korelasyon katsayısı analizi, araştırmacıların inceledikleri özellikler arasındaki anlamlı ilişkiyi ayırt etmelerine yardımcı olmaktadır. Çalışmaya ait korelasyon katsayısı analizi sonuçları Çizelge 5’te verilmiştir. Diyarbakır lokasyonunda tane verimi ile tanede protein içeriği yönünden olumsuz önemli $\left(\mathrm{r}=-0.412^{*}\right)$ ilişki belirlenmiştir. Hektolitre ağırlığı ile tanede protein içeriği ve tanede nişasta içeriği (sırasıyla, $\mathrm{r}=0.572^{* *}, \mathrm{r}=0.774^{* * *}$ ) arasinda olumlu ve önemli ilişki belirlenmiştir.

Mardin lokasyonunda ise sadece hektolitre ağırlığı ile tanede protein içeriği $\left(\mathrm{r}=0.567^{* *}\right)$ arasında olumlu ve önemli ilişki belirlenmiştir. Her iki lokasyonda hektolitre ağırlığı ile tanede protein içeriği arasında olumlu ve önemli ilişki belirlenmiştir. Kızılgeçi ve ark. (2016 b) bu çalışmaya benzer olarak hektolitre ve protein arasında olumlu ve önemli ilişki olduğunu bildirmişlerdir.

Çizelge 5. Diyarbakır ve Mardin lokasyonlarında incelenen özellikler arası korelasyon ilişkisi

\begin{tabular}{|c|c|c|c|c|c|c|}
\hline \multicolumn{7}{|l|}{ Diyarbakır } \\
\hline Özellikler & SPAD & $\begin{array}{c}\text { Tane } \\
\text { verimi }\end{array}$ & $\begin{array}{c}\text { Tanede } \\
\text { protein içeriği }\end{array}$ & $\begin{array}{c}\text { Tanede } \\
\text { nişasta içeriği }\end{array}$ & $\begin{array}{l}\text { Hektolitre } \\
\text { ağırlığ }\end{array}$ & $\begin{array}{l}\text { Bin tane } \\
\text { ağırliğ1 }\end{array}$ \\
\hline SPAD & 1 & & & & & \\
\hline Tane verimi & 0.317 & 1 & & & & \\
\hline Tanede protein içeriği & -0.302 & $-0.412^{*}$ & 1 & & & \\
\hline Tanede nişasta içeriği & -0.153 & $0.445^{*}$ & 0.225 & 1 & & \\
\hline Hektolitre ağırlı̆̆ & -0.352 & 0.189 & $0.572^{* *}$ & $0.774^{* * *}$ & 1 & \\
\hline Bin tane ağırlığı & 0.1645 & 0.090 & 0.115 & 0.259 & 0.228 & 1 \\
\hline \multicolumn{7}{|c|}{ Mardin } \\
\hline SPAD & 1 & & & & & \\
\hline Tane verimi & -0.270 & 1 & & & & \\
\hline Tanede protein içeriği & 0.221 & -0.204 & 1 & & & \\
\hline Tanede nişasta içeriği & 0.227 & -0.051 & 0.142 & 1 & & \\
\hline Hektolitre ağırlığ 1 & 0.157 & -0.082 & $0.567^{* *}$ & 0.337 & 1 & \\
\hline Bin tane ağırlığı & 0.166 & 0.241 & 0.242 & -0.292 & 0.125 & 1 \\
\hline
\end{tabular}

$* *, * * * \% 1$ ve \% 0.1düzeyinde önemli 


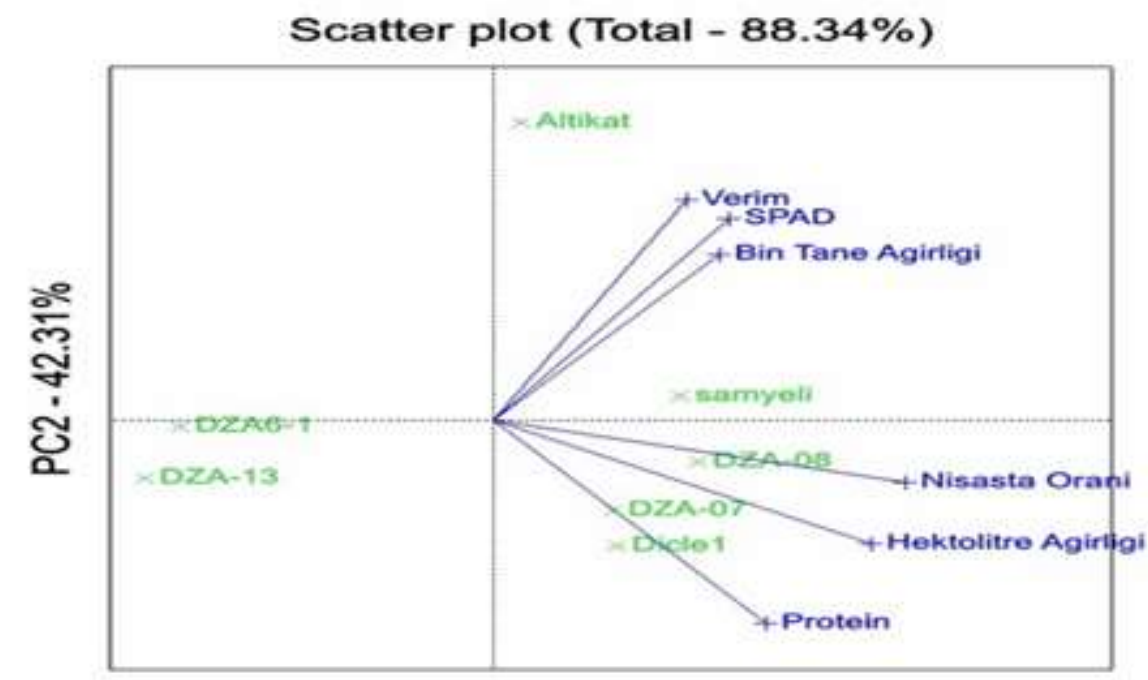

PC1 - 46.04\%

Şekil 1. Genotip-özellik ilişkisinin gruplara ayrılması

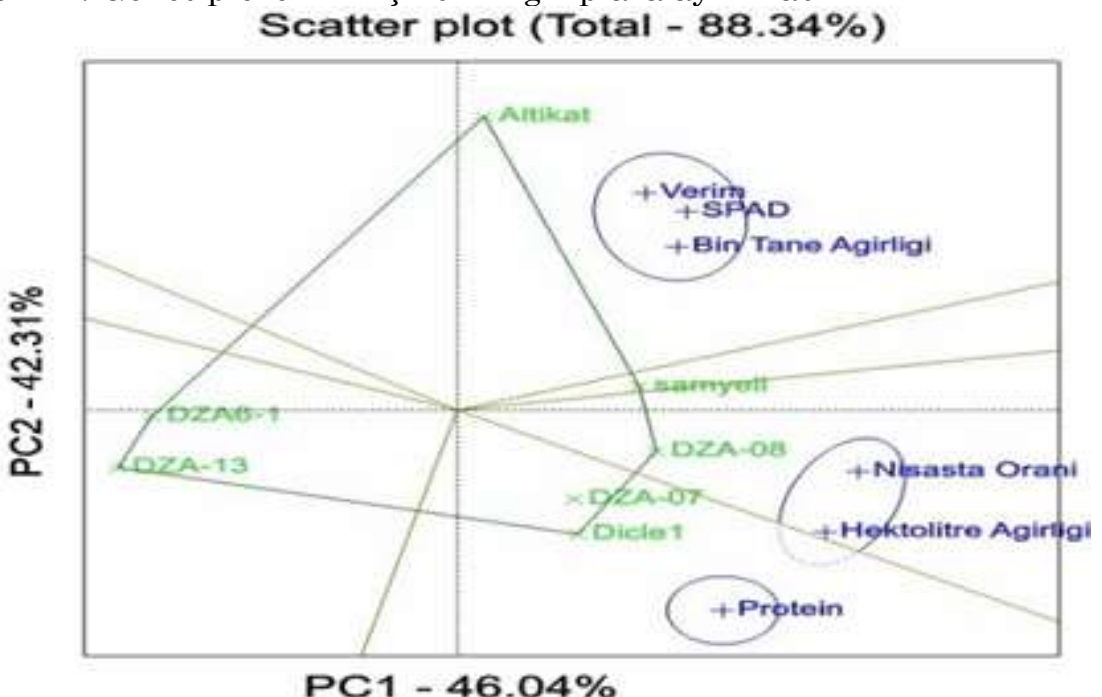

Şekil 2. İncelenen özelliklere ait genotip-özellik ilişkisini gösteren biplot grafiği

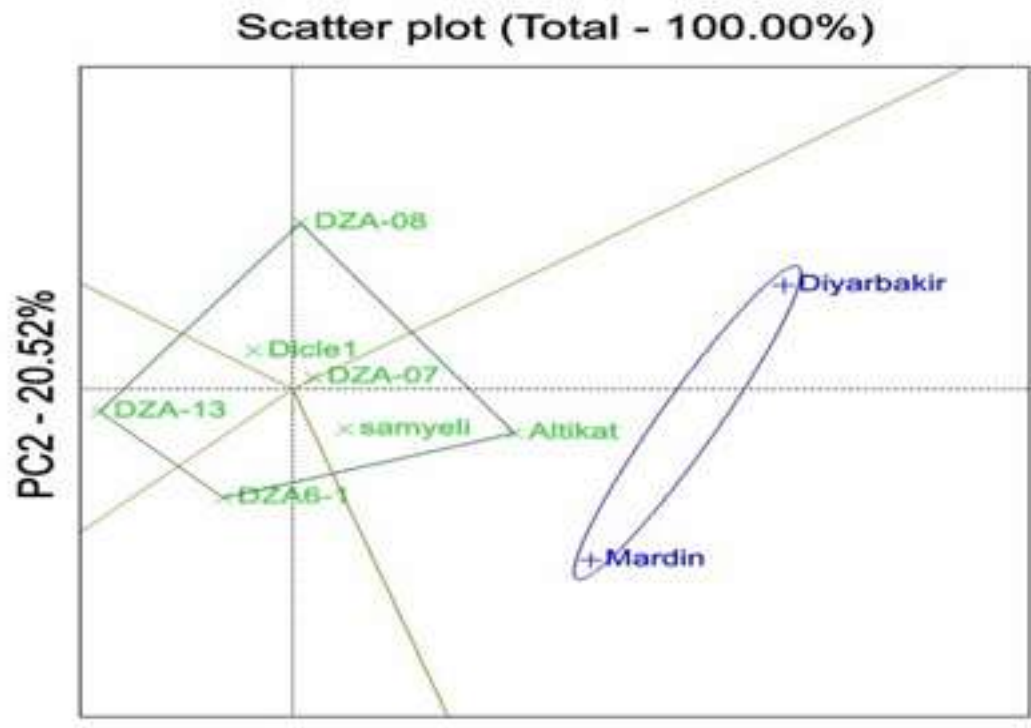

PC1 - 79.48\%

Şekil 3. Genotip- lokasyon ilişkisini gösteren biplot grafiği 


\section{Biplot Analiz Sonuçları ve Grafiklerin Yorumlanması}

7 arpa genotipinin tane verimi ve kalite özellikleri ile lokasyonlar arasındaki çoklu değişken ilişkileri belirlemek için hem genotipler hem de incelenen özelliklerin temel bileşen analizi (PCA) PC1 ve PC2 değerleri karşılaştırılarak biplot analizi gerçekleştirilmiştir. Çalışmada incelenen özelliklerin genotiplere göre sinıflandırılması ve genotiplerin özelliklere göre değişimi Şekil 1 ve Şekil 2'de gösterilmiştir. GGE Biplot grafiği incelendiğinde; PC1 (1. temel bileşen) \% 46.04 ve PC2 (2. temel bileşen) \% 42.31 toplamda varyasyonun \% 88.34'ünü oluşturmuştur. Yan ve ark., (2000), iki temel bileşenin toplam değerinin \%100'e yaklaşması incelenen özelliklerin katsayılarının yüksek olduğunu bildirmiş̧lerdir. Genel olarak incelenen özelliklerin 2 farklı grup oluşturduğu görülmektedir. İlk grup tane verimi, SPAD ve bin tane ağırlığı özelliklerine ait vektörler arasındaki açı değerinin $90^{\circ}$ düşük olduğundan bu 3 özellik aynı grupta yer almışlardır. İkinci grup ise nişasta içeriği, hektolitre ağırlığ ve protein içeriğine ait vektörler arasındaki açı $90^{\circ}$ den düşük bulunmuş ve bu özellikler aynı grupta yer almıştır. Protein içeriği özelliği ile tane veriminin ayrı sektörlerde yer alması ve aralarındaki vektörel açının $90^{\circ}$ 'den yüksek olması bu özellikler arasında ilişkinin zayıf olduğunu göstermektedir. Biplot grafiği incelendiğinde poligon köşegenlerinde yer alan Altıkat, tane verimi, bin tane ağırlığ ve SPAD bakımından, DZA-7, DZA-08 ve Dicle1 tanede protein içeriği, hektolitre ağırlığı ve tanede nişasta içeriği yönünden ön plana çıkmışlardır.

DZA-6-1 ve DZA-13 genotiplerinin herhangi bir özellikle ilişkileri olmadığından, herhangi bir grupta yer almamışlardır. Araştırmada incelenen özelliklerin GGE Biplot analiz yöntemi ile gruplandırılması ve genotiplerin incelenen özelliklerle olan ilişkisi yönünden ön plana çıkan Altıkat çeşidi olmuştur. Ayrıca aynı grupta yer alan özelliklere yakın olan ve PC2 değeri, ortalama PC2 değeri olan sıfir " 0 " değerine yakın olan Samyeli çeşidi sahip olduğu özellikleri koruma kararlılığının yüksek olduğu söylenebilir. Yapılan Biplot analizine göre PC1 (\%79.48) ve PC2 (\%20.52) varyasyonun toplam \%100'nü oluşturmaktadır (Şekil 3). İncelenen özellikler yönünden genotip ile çevre ilişkisini gösteren GGE Biplot grafiğine göre, çalışmada yer alan genotiplerin 4 bölgeye ayrıldığı, lokasyonların ise aynı sektörde yer aldığı görülmüştür. Poligonların köşegenlerinde yer alan genotipler en duyarl genotipler olarak belirlenmiştir. Diyarbakır ve Mardin çevrelerinin birlikte yer aldıkları mega çevreyi en iyi temsil eden Altıkat çeşidi olmuştur.

Poligonun diğer köşelerinde yer alan DZA6-1, DZA13 ve DZA-08 hatları bu çevreleri temsil eden en kötü genotipler olmuşlardır. Biplot grafiğinin orijin noktası yakınında yer alan DZA-07 genotip incelenen özellikler yönünden çevre değişimlerinden en az etkilenen genotip olduğu görülmüştür.

\section{SONUÇ}

Çalışma sonucuna göre, genotip, çevre ve onların interaksiyonunun Diyarbakır ve Mardin lokasyonlarında yetiştirilen arpa genotiplerinin verim ve kalite özellikleri üzerine yüksek etkiye sahip olduğu görülmüştür.

Her iki lokasyonda tane verimi yönünden Altıkat çeşidi en yüksek değere sahip olmuştur. DZA7, DZA8 ve Dicle 1 hatları birçok kalite (protein içeriği, hektolitre ağırlığı ve nişasta içeriği) özellikleri yönünden ön plana çıkan hatlar olmuşlardır. $\mathrm{Bu}$ hatların daha özel amaçlarda kullanmak için çeşit adayı olabilecekleri kanısına varılmıştır. Biplot analiz yöntemi farklı lokasyonlarda incelenen arpa genotiplerinin verim ve kalite performanslarını görsel açıdan değerlendirmede fayda sağlamıştır.

\section{KAYNAKLAR}

Ahmadi J, Vaezi B, Pour-Aboughadareh A 2016. Analysis of variability, heritability, and interrelationships among grain yield and related characters in barley advanced lines. Genetika, 48(1): 73-85.

Akıncı C, Gül İ, Çölkesen M 1999. Diyarbakır koşullarında bazı arpa çeşitlerinin tane ve ot verimi ile bazı verim unsurlarının belirlenmesi. Türkiye 3 . Tarla Bitkileri Kongresi, 15-20 Kasım 1999, Cilt:1, 405-410, Adana.

Akıncı C, Yıldırım M, Sönmez N 2001. Diyarbakır koşullarına uygun arpa çeşitlerinin belirlenmesi. Türkiye 4. Tarla Bitkileri Kongresi, 17-21 Eylül 2001, Cilt 1, 151-156, Tekirdağ.

Akıncı C, Yıldırım M 2009. Screening of barley landraces by direct selection for crop improvement. Acta Agriculturae Scandinavica, Section B - Plant Soil Science, 59(1): 33-41.

Aydoğan S, Şahin M, Akçacık AG, Ayrancı R 2011. Konya koşullarına uygun yüksek verimli ve kaliteli arpa genotiplerinin belirlenmesi. Selçuk Tarım ve Gida Bilimleri Dergisi, 25 (1): 10-16.

Çölkesen M, Eren N, Öktem A, Akıncı C 1994. Harran ovası sulu koşullarında farklı ekim sıklığının arpa çeşitlerinde verim ve verim unsurlarma etkisi üzerine bir araştırma. Türkiye 1. Tarla Bitkileri Kongresi, Cilt I, Agronomi Bildirileri, 13-17, İzmir.

Doorenbos J, Kassam, AH 1979. Yield response to water FAO Irrigation and Drainage Paper No:33. Food and Agriculture Organization of United Nations. Rome.

Elgün A, Türker S, Bilgiçli N 2001. Tahıl ve ürünlerinde analitik kalite kontrolü. Selçuk Üniversitesi Ziraat Fakültesi Gıda Mühendisliği Bölümü, Yayın No: 2, Konya. 
FAOSTAT 2017. Statistics Division of Food and Agriculture Organization of the United Nations.http://faostat3.fao.org/browse/Q/QC/E. (Erişim tarihi: 08/03/2017).

Fotokian MH, Agahi K, Ahmadi J, Vaezi B 2014. Selection of barley advanced lines at rainfed conditions using regression and cluster analyses. Int. J. Biosci, 4(6): 80-88.

Geçit HH 1982. Ekmeklik buğday ( $T$. aestivum L. Em Thell) çeşitlerinde ekim sıklıklarına göre birim alan değerleri ile ana sap ve çeşitli kademedeki kardeşlerin tane verimi ve verim komponentleri üzerine araştırmalar. Ankara Üniversitesi Zir. Fak. Tarla Bit. Böl., Doçentlik Tezi, 91 s.

Geçit HH 2016. Serin İklim Tahılları (Buğday, Arpa, Yulaf, Triticale). Ankara Üniversitesi, Ziraat Fakültesi, Yayın No: 1640, Ankara, 822s.

Iravani M, Solouki M, Rezai AM, Siasar BA, Kohkan SA. (2008). Investigating the diversity and relationship between agronomical traits and seed yield in barley advanced lines using factor analysis. JWSS-Isfahan University of Technology, 12(45): 137-145.

Kaydan D, Yağmur M 2007. Van ekolojik koşullarında bazı iki sıralı arpa çeşitlerinin (Hordeum vulgare L. conv. distichon) verim ve verim öğeleri üzerine bir araştırma, Ankara Üniversitesi Tarım Bilimleri Dergisi. 13 (3): 269-278.

Kendal E, Tekdal S, Aktaş H, Karaman M, Berekatoğlu K, Doğan H 2014. Biplot analizi kullanılarak yazlık arpa genotiplerinin verim ve verim unsurlarının belirlenmesi. Trakya University Journal of Natural Sciences, 15(2): 95103.

Kılıç H, Akar T, Kendal E, Sayım İ 2010. Evaluation of grain yield and quality of barley varieties under rainfed conditions. African Journal of Biotechnology, 9(46): 7825-7830.

Kızılgeçi F, Yıldırım M, Akıncı C, Albayrak Ö 2016a. Bazı arpa genotiplerinin Diyarbakır ve Mardin koşullarında verim ve kalite parametrelerinin incelenmesi. Iğdır Üniversitesi Fen Bilimleri Enstitüsü Dergisi, 6(3): 161-169.

Kızılgeçi F, Yıldırım M, Akıncı C, Albayrak Ö, Biçer BT, Başdemir F 2016b. Bazı arpa genotiplerinin Diyarbakır ve Şanlıurfa Koşullarında verim ve kalite özellikleri açısından incelenmesi. Tarla Bitkileri Merkez Araştırma Enstitüsü Dergisi, (Özel Sayı-1): 146-150.

Kızılgeçi F, Yıldırım M 2017. Bazı tritikale (X
Triticosecale Wittmack) genotiplerinin verim ve kalite özelliklerinin belirlenmesi. Türkiye Tarımsal Araştırmalar Dergisi. 4(1): 43-49.

Kizilgeci F, Yildirim M, Akinci C, Albayrak O, Sesiz U, Tazebay N 2018. Evaluation of relationships between yield and yield components with physiological parameters in barley (Hordeum vulgare L.) genotypes. DUFED. 7(2): 61- 66.

Mishra SC, Singh SK, Patil R, Bhusal N, Malik A, Sareen S 2014. Wheat: recent trends on production strategies of wheat in India Edition: 1stChapter: Breeding for heat tolerance in Wheat. Publisher: DWR, Karnal Editors: RS Shukla, PC Mishra, R Chatrath, RK Gupta, SS Tomar, Indu Sharma.

Öztürk İ, Avcı R, Kahraman T 2007. Trakya Bölgesinde yetiştirilen bazı arpa (Hordeum vulgare L.) çeşitlerinin verim ve verim unsurları ile bazı kalite özelliklerinin belirlenmesi. Uludağ Üniversitesi Ziraat Fakültesi Dergisi, 21(1): 59-68.

Tekdal S, Kendal E, Aktaş H, Karaman M, Kılıç H, Kızılgeçi F 2013. ICARDA orijinli bazı durum buğday genotiplerinin Diyarbakır şartlarına uyum kabiliyetlerinin araştırılması. Türkiye 10. Tarla Bitkileri Kongresi, Bildiriler :10-13 Eylül, Konya, 743-749.

TUIK 2018. Türkiye İstatistik Kurumu. www.tuik.gov.tr (Erişim tarihi : 20/09/2018)

Vaezi B, Ahmadi J, Pour-Aboughadareh A 2105. Stability analysis for barley advanced lines under Gachsaran tropical conditions. Cereal Research, 5(3): 261-27.

Yan W, Hunt LA, Sheng Q, Szlavnics Z 2000. Cultivar evaluation and mega-environment investigation based on GGE biplot. Crop Science, 40:597- 605 .

Yan W 2001. GGE Biplot- A Windows application for graphical analysis of multi-environment trial data and other types two-way data. Agronomy Journal, 93: 1111-1118.

Yan W, Kang MS 2002. GGE biplot analysis: A graphical tool for breeders, geneticists and agronomists. CRC pres,

Yan W, Tinker NA 2006. Biplot analysis of multienvironment trial data: principles and applications. Canadian Journal of Plant Science 86: 623-645.

Yan W, Kang MS, Ma B, Woods S, Cornelius, PL 2007. GGE biplot vs. AMMI analysis of genotype-byenvironment data. Crop Science, 47: 643-655.

Yau SK 1995. Regression and AMMI analyses of genotype $\times$ environment interactions: An empirical comparison. Agronomy Journal, 87: 121-126. 